\author{
Andrzej Tokarski \\ Wyższa Szkoła Bankowa w Toruniu
}

\title{
Globalizacja a ryzyko bankructwa przedsiębiorstw
}

Jedną z ostro nasilających się w ostatnich latach cech gospodarki i funkcjonowania przedsiębiorstwa jest rosnąca niepewność. Coraz częściej przedsiębiorstwa, kraje i całe regiony gospodarki globalnej zaskakiwane są przez sploty wydarzeń oraz negatywnych, trudnych do przewidzenia i opanowania zjawisk gospodarczych. Spektakularnym tego dowodem jest kryzys finansowy w gospodarce Stanów Zjednoczonych, który rozpoczął się w 2007 r., a którego następstwa dotknęły także inne kraje (Mączyńską 2010g, s. 46). Odzwierciedla to skomplikowaną sieć powiązań w zglobalizowanej i globalizującej się coraz bardziej gospodarce światowej. Występuje tu swego rodzaju efekt domina, dotyczący zwłaszcza bankructw przedsiębiorstw (Mączyńską 2009b, s. 273).

Niepewność i nietrwałość to cecha współczesnej gospodarki wynikająca przede wszystkim z niebywałej gwałtowności, głębokości, intensywności oraz bezprecedensowego dynamizmu innowacji, w tym finansowych, przemian i postępu technologicznego dokonującego się w skali światowej. Towarzyszą temu niezrównoważony, niestety, wzrost gospodarczy i pogłębiające się dysproporcje rozwojowe w skali globalnej. Najbardziej spektakularne przejawy tej sytuacji to bezrobocie i obszary nędzy (przy równoczesnej koncentracji bogactwa), wynaturzenia w relacji między rolą państwa w poszczególnych krajach a siłą ponadnarodowych korporacji, czemu towarzyszą przetaczające się przez świat fale bankructw przedsiębiorstw. Listę tę powiększają narastające zagrożenia dla środowiska naturalnego i jego równowagi oraz rozmaite inne patologie w gospodarce, społeczeństwie i polityce, przy czym szczególnie groźne są konflikty wynikające z cywilizacyjnego podziału i skrajnego zróżnicowania świata.

\section{Aspekt ekonomiczny i prawny upadłości}

Upadłości i bankructwa przedsiębiorstw są nieodłącznym elementem gospodarki rynkowej (Bauer 2009). Stanowią następstwo utraty przez przedsiębiorstwa zdolności do spłaty długów (Tokarski 2009), pełnią tym samym funkcję niezbędnej selekcji w biznesie, w tym racjonalizacji, oczyszczania rynku z jednostek niemogących sprostać wymogom efektywności. Stanowi to zarazem element ochrony wierzycieli i innych jednostek.

Pojęcia bankructwo i upadłość traktowane są jako synonimy (Mączyńska 20091, s. 241). Nie jest to precyzyjne, albowiem bankructwo to pojęcie z zakresu przede wszystkim ekonomii, podczas gdy upadłość to w zasadzie kategoria prawna („Kwartalnik Nauk o Przedsiębiorstwie” 2009, s. 4). Utożsamianie bankructwa z upadłością jest zasadne jedynie w przypadku upadłości zawinionej (podlegającej karze współmiernej do winy, co regulują szczegółowe przepisy).

Upadłość niezawiniona natomiast nie jest traktowana jako bankructwo w sensie ekonomicznym, albowiem nie wynika z nieprawidłowości w zarządzaniu przedsiębiorstwem, lecz z przyczyn leżących poza nim, np. z powodu oszustwa przez kontrahenta.

Różnice między bankructwem a upadłością przedstawia tabela 1. 
Tab. 1. Upadłość a bankructwo

\begin{tabular}{|c|c|c|c|}
\hline Upadłość $\neq$ bankructwo & \multicolumn{3}{|c|}{ Upadłość $=$ bankructwo } \\
\hline \multirow{2}{*}{ niezawiniona } & \multicolumn{3}{|c|}{ zawinione } \\
\hline \multirow{2}{*}{ nie podlega karze } & nieumyślne & umyślne & umyślne z chęci zysku \\
\cline { 2 - 4 } & \multicolumn{2}{|c|}{$\begin{array}{c}\text { podlega karze } \\
\text { prawa sprawowania określonych funkcji, kara pozbawienia wolności) }\end{array}$} \\
\cline { 2 - 4 } & kara łagodniejsza & kara ostrzejsza & \multicolumn{2}{|c|}{ kara najostrzejsza } \\
\cline { 2 - 4 }
\end{tabular}

Źródło: E. Mączyńska, Ocena ryzyka upadłości przedsiębiorstwa [w:] A. Fierla, Ryzyko w działalności przedsiębiorstw. Wybrane aspekty, SGH, Warszawa 2009, s. 58.

Z punktu widzenia ekonomii bankrutem jest przedsiębiorstwo, które nie jest w stanie regulować swoich długów oraz wartość jego majątku nie wystarcza na pokrycie wszystkich zobowiązań (bankrutem jest także firma, która mimo iż zaistniały powyższe przesłanki nadal prowadzi działalność).

W aspekcie prawnym upadłość przedsiębiorstwa następuje dopiero po ogłoszeniu bankructwa przez sąd. Ma to na celu równomierne zaspokojenie wszystkich wierzycieli dłużnika, który nie jest w stanie zaspokoić każdego z osobna. Powinno zapobiec prowadzeniu egzekucji przeciwko dłużnikowi przez niektórych tylko wierzycieli (w wypadku, gdy inni nie mają jeszcze tytułu egzekucyjnego, np. wtedy, gdy ich wierzytelności nie są jeszcze płatne) oraz w przypadku, gdy istnieje system pierwszeństwa w postępowaniu egzekucyjnym. Oznacza to, że fakt bankructwa jest ustalany sądownie na podstawie wniosku skierowanego bądź to przez dłużnika, bądź przez któregoś z wierzycieli lub przez kilku wierzycieli. W pierwszym przypadku można mówić o bankructwie dobrowolnym, w drugim - o bankructwie przymusowym.

Główną przesłanką do złożenia wniosku o ogłoszenie upadłości w wypadku prawodawstwa polskiego jest zaprzestanie płacenia zobowiązań w długim okresie czasu. Tak więc krótkotrwałe wstrzymanie płacenia długów, wskutek przejściowych trudności, nie jest podstawą do ogłoszenia upadłości. Przepisy prawa stanowią, iż upadłość ogłasza się w stosunku do dłużnika, który stał się niewypłacalny (Tokarski A., Tokarski M. 2006). Zgodnie z artykułem 11 Prawa upadłościowego i naprawczego „dłużnik jest niewypłacalny, jeżeli nie wykonuje swoich wymagalnych zobowiązań, przy czym za niewypłacalny uważa się podmiot wtedy, gdy jego zobowiązania przekraczają wartość majątku, nawet wtedy gdy na bieżąco te zobowiązania wykonuje (Prawo upadłościowe i naprawcze 2003).

Drugą przesłanką może być wystąpienie nadwyżki stanu czynnego nad stanem biernym. W języku ekonomicznym oznaczałoby to brak możliwości pokrycia wszystkich zobowiązań z posiadanego majątku.

Bankructwo w sensie ekonomicznym nie musi oznaczać upadłości w sensie prawnym, ale każda upadłość ogłoszona przez sąd oznacza bankructwo ekonomiczne. 
Globalizacja bankructw jako następstwo nowego paradygmatu cywilizacyjnego kapitalizmu globalnego (postindustrialnego)

Postępujące procesy globalizacji, rozwój rynków kapitałowych i przedsiębiorstw ponadnarodowych oraz złożona i zagęszczająca się w wyniku tego sieć powiązań (globalna pajęczyna) w gospodarce sprawiają, że nie tylko gospodarka, przedsiębiorstwa, ale i ryzyko podlegają globalizacji. Dotyczy to także ryzyka bankructwa (Kuciński, Mączyńska 2005). Praktyka wykazuje przy tym, że wirus bankructwa rozprzestrzenia się tym szybciej, im silniejsze są powiązania zaatakowanego chorobą niewypłacalności przedsiębiorstwa z innymi, krajowymi i zagranicznymi partnerami. Globalizacja potęguje siłę rozprzestrzeniania się bankructw (Mączyńska 2004d, s. 105).

Gospodarka we współczesnym świecie nabiera w coraz większym stopniu cech gospodarki nietrwałości. Nietrwałe stają się profesje, stanowiska pracy i pozycje w hierarchii menedżerskiej. Ponadnarodowym fuzjom i przejęciom towarzyszy powstanie nowej grupy zatrudnionych korporacyjnych cyganów (Mączyńska 2008c, s. 17). Nietrwałe stają się byty produkcyjne, jak również teorie, w tym ekonomiczne.

Każda cywilizacja ma swój model funkcjonowania społeczeństwa i gospodarki. Zmiana paradygmatu cywilizacyjnego wypiera dotychczasowe modele nie tylko gospodarki i produkcji w ogóle, ale i zarządzania, inwestowania, handlu, kształcenia, pracy, zatrudnienia. Przekształca się większość metod komunikowania się, produkowania i wymiany handlowej.

Procesy te są przedmiotem wielu analiz i publikacji, m.in. szczegółowej analizie poddał je A. Toffler przede wszystkim w osławionej Trzeciej fali. Jednakże obecnie dynamika przemian jest tak wielka, że Tofflerowska trzecia fala to już prawie przeszłość, historia, a z drugiej strony, pierwsza fala, czyli cywilizacja bazująca na osiadłym rolnictwie, dopiero niedawno „skończyła ogarniać glob” (Mączyńska 2009a, s. 129).

Natomiast druga fala, która w XVIII w. przyniosła rewolucję przemysłową, prowadząc do rozwoju społeczeństwa industrialnego, choć nadal obejmuje kolejne obszary i społeczeństwa, znajduje się w fazie schyłkowej i jest skazana na wygasanie.

Następująca po niej trzecia fala, bazująca na rozwoju mikroelektroniki, poganiana jest już przez kolejne. Fala czwarta to rewolucja w sferze informacji (Internet), co z kolei sprzyja ponadnarodowym przepływom kapitałowym - piątej fali (światowe fuzje i przejęcia). Natomiast współczesny rozwój naukowo-techniczny oraz rozstrzygająca rola informacji, wiedzy i kwalifikacji tworzą nowy paradygmat rozwojowy, tj. gospodarkę opartą na wiedzy (a raczej na potencjale intelektualnym). Przy tym wiedza, informacja to specyficzne, całkiem odmienne od tradycyjnych, źródło bogactwa: nie zużywa się, kto je sprzedaje, posiada je nadal. Wiedza staje się uniwersalnym substytutem. Można ją jednocześnie wykorzystywać do tworzenia bogactwa i pomnażania samej wiedzy. W przeciwieństwie do dóbr materialnych i surowców, jest niewyczerpywalna. Tworzy to potencjał produktywności tak duży, że najwyżej rozwinięte społeczeństwa będą w stanie pójść w kierunku modelu społeczeństwa czasu wolnego i rozrywki. Ma to charakter swego rodzaju szóstej fali, która obejmuje na razie tylko najbardziej uprzywilejowane społeczeństwa. Zarazem wygospodarowany czas wolny służyć może kreatywności, która staje się podstawowym czynnikiem bogactwa. 
Tab. 2. Przemiany cywilizacyjne

\begin{tabular}{|c|c|c|c|}
\hline Cywilizacje & $\begin{array}{c}\text { Zmiany systemu - } \\
\text { ustroju } \\
\text { gospodarczego }\end{array}$ & $\begin{array}{l}\text { Zmiany typu } \\
\text { przekazu, } \\
\text { komunikacji }\end{array}$ & $\begin{array}{c}\text { Wladza i podwładni } \\
\text { (górne i dolne warstwy } \\
\text { spoleczne) }\end{array}$ \\
\hline I. Rolna & feudalizm & epoka słowa pisanego & $\begin{array}{l}\text { feudałowie - } \\
\text { chłopi feudalni }\end{array}$ \\
\hline II. Industrialna & kapitalizm & $\begin{array}{c}\text { epoka słowa drukowa- } \\
\text { nego }\end{array}$ & $\begin{array}{c}\text { fabrykanci, bankierzy - } \\
\text { pracownicy, robotnicy } \\
\text { najemni }\end{array}$ \\
\hline $\begin{array}{l}\text { III. Postindustrialna } \\
\text { - trzecia fala (Toffler) }\end{array}$ & \multirow[t]{5}{*}{$\begin{array}{l}\text { kapitalizm (????) } \\
\text { postindustrialny }\end{array}$} & \multirow[t]{5}{*}{$\begin{array}{l}\text { epoka języka } \\
\text { cyfrowego }\end{array}$} & \multirow{5}{*}{$\begin{array}{c}\text { netokracja (sieciowa } \\
\text { arystokracja) - } \\
\text { konsumtariat }\end{array}$} \\
\hline IV. Internet & & & \\
\hline $\begin{array}{l}\text { V. Ponadnarodowe } \\
\text { fuzje i przejęcia }\end{array}$ & & & \\
\hline $\begin{array}{l}\text { VI. Gospodarka oparta } \\
\text { na wiedzy }\end{array}$ & & & \\
\hline $\begin{array}{l}\text { VII. Wiek } \\
\text { kreatywności }\end{array}$ & & & \\
\hline
\end{tabular}

Źródło: E. Mączyńska, Sytuacje kryzysowe w przedsiębiorstwach [w:] I. Lichniak, Nauka o przedsiębiorstwie. Wybrane zagadnienia, SGH, Warszawa 2009, s. 201.

Wszystkie wymienione fale cywilizacyjne łączyły się z kryzysami w sferze produkcji. Producenci, którzy nie mogli przystosować się do nowych wymogów, w skrajnych wypadkach bankrutowali. Na innych zaś sytuacja kryzysowa wymuszała przemiany prowadzące do sukcesu.

Obecnie zmiany wzorca cywilizacyjnego są szczególnie głębokie. Tradycyjny fabryczny, przemysłowy kapitalizm wypierany jest przez nowy model gospodarki, model, którego kształt jeszcze do końca nie został rozpoznany i który nazywany jest różnie: kapitalizmem globalnym, kapitalizmem trzeciej fali lub postkapitalizmem.

\section{Upadłość a globalna niepewność}

Dokonującym się w skali globalnej przełomowym zmianom towarzyszy narastanie niepewności we wszystkich niemalże obszarach życia ekonomicznego i społecznego. Niepewność zaś w odróżnieniu od ryzyka jest niemierzalna, stąd też w ocenach przemian gospodarczych i społecznych kwestia ta jest często bagatelizowana, co prowadzi do ambiwalentności ocen. Ambiwalencja przejawia się zarówno w sferze makro-, jak i mikroekonomicznej, w sferze teorii oraz praktyki.

Bezprecedensowe szybkie tempo przemian sprawia, że teoria często nie przystaje do praktyki, zaś doświadczenia z przeszłości nie wystarczają, a podstawową umiejętnością staje się zapominanie, wyzbywanie się starych nawyków i wzorców. Zarazem największą barierą rozwojową staje się niewiedza o własnej niewiedzy. Bardzo przystaje tu myśl Konfucjusza: „Wiedzieć, że się wie, co się wie i wiedzieć, że się nie wie, czego się nie wie - oto prawdziwa wiedza" (Sztucki 2000). 
Cykle życia wiedzy stają się coraz krótsze, czemu towarzyszy wydłużanie się życia ludzkiego. Stąd też wiedza staje się coraz bardziej niedemokratyczna, skrajnie różnicując podmioty i ich szansę. Nowa fala cywilizacyjna zatapia nieprzygotowanych, których stale przybywa. Przysparza pracy osobom wysoko wykwalifikowanym, skazując na bezrobocie innych.

Paradoksalnie jednak w epoce gospodarki opartej na wiedzy w gruncie rzeczy ma się do czynienia z ekonomią niedoskonałej wiedzy, wiedzy niepewnej. W takich warunkach ,niedoskonała jest prawda i nieprawdziwa pewność?" (Mączyńska 2009e, s. 58). Ekonomia zaś jest nauką bazującą na badaniu pewnych regularności, prawidłowości. Jeśli natomiast czasy są burzliwe, to powstają trudności ze zidentyfikowaniem tych regularności, prawidłowości. Dlatego też niezbędna jest zmiana podejścia w naukach ekonomicznych. Obecnie modele, w tym matematyczne, zawodzą. Bazują bowiem na pewnych założeniach trwałych i prawidłowościach, zatem w warunkach gwałtownych przemian stają się mniej przydatne. W kształtowaniu strategii konieczne jest podejście holistyczne, z uwzględnieniem nie tylko kwestii ekonomicznych, ale także społecznych i ekologicznych, bo przecież najlepsza nawet teoria ekonomii, ale bez uwzględnienia czynnika społecznego, człowieka, bez analizy zachowań ludzkich, nie może przynieść satysfakcjonujących efektów.

\section{Ucywilizować procesy bankructwa}

Upadłość to nie tylko problem słabo zdiagnozowany, nierzadko to temat tabu. Wyraźna jest bowiem tendencja do uznawania bankructwa za problem wyłącznie przedsiębiorstw słabych.

Podstawowym problemem w funkcjonowaniu współczesnych przedsiębiorstw jest gwałtowność i zawiłość przemian cywilizacyjnych, jakim obecnie podlega gospodarka w skali światowej i lokalnej. Przemiany te sprawiają, że obok beneficjentów, rośnie liczba ofiar. Głębokie przemiany zawsze obarczone są dużym ryzykiem, zważywszy zwłaszcza na rosnącą w warunkach globalizacji łatwość rozprzestrzeniania się sytuacji kryzysowych i wirusa bankructwa (Mączyńska 2009h, s. 8). Odpowiednio szybkie identyfikowanie szans i zagrożeń przedsiębiorstw jest niezbędnym czynnikiem optymalizacji bieżących i strategicznych decyzji, podejmowanych na różnych szczeblach zarządzania.

Niedorozwój w sferze teorii i praktyki upadłości występuje w wielu krajach Unii Europejskiej, w tym także Polski, i świata. Choć świat się globalizuje, globalizuje się biznes, to ciągle jeszcze czyni się zbyt mało, aby w skali globalnej „ucywilizować”, zracjonalizować procesy bankructwa, mimo że z bankructwem przedsiębiorstwa może się wiązać globalny efekt domina (Tokarski 2010).

Działania na rzecz ucywilizowania bankructwa podjęła dopiero w 2004 r. Unia Europejska. Zostały one podjęte w ramach projektu Stigma of failure and early warning tools, którego głównymi celami są:

- opracowanie materiałów informacyjnych dotyczących radzenia sobie z piętnem związanym $\mathrm{z}$ bankructwem,

- opracowanie narzędzi wczesnego ostrzegania służących zapobieganiu upadłości.

W UE podejmowane są też działania praktyczne, ukierunkowane na:

- wspieranie przedsiębiorstw przeżywających trudności,

- usuwanie przeszkód na drodze do drugiej szansy.

Nieprawidłowości w funkcjonowaniu prawa upadłościowego dotyczą także Polski. Mimo zmiany tego prawa, w praktyce nadal wyraźnie widać jego ułomności Przede wszystkim ciągle niedoceniany jest drugi nurt w prawie upadłościowym - nurt naprawczy. Wierzyciele chcą raczej jak najszybciej odzyskać swoje wierzytelności, odzyskać to, co jest jeszcze możliwe. Procesy naprawcze często nie są brane pod uwagę, nawet jeśli istnieją szanse na uzdrowienie. 
Badania wykazują, że bankructwa w naszym kraju są znacznej części wyreżyserowane, a ich przyczyny nie mają cech przyczyn czysto ekonomicznych (Mączyńska 2010i, s. 145). Potwierdzają to opinie praktyków, w tym sędziów sądu gospodarczego. Paradoksalnie, wbrew nazwie ustawy Prawo upadłościowe i naprawcze, marginalizowane są naprawy na rzecz likwidacji i upadłości przedsiębiorstw. Przedsiębiorcy w postępowaniu naprawczym widzą raczej zagrożenie dla swojego wizerunku i pozycji rynkowej, aniżeli szanse na wybrnięcie z doraźnych problemów i poprawie własnej konkurencyjności.

Współcześnie funkcjonowanie przedsiębiorstw charakteryzują rosnące napięcia, rosnący stopień ryzyka i niepewności, co znajduje odzwierciedlenie w rosnącym zagrożeniu bankructwem.

Jedną z zasadniczych przyczyn ograniczeń przemian ukierunkowanych na równoważnie wzrostu gospodarczego i łagodzenie napięć jest niedostosowanie zasad ustroju gospodarczego do wymogów nowego paradygmatu cywilizacyjnego, do dokonującego się przełomu cywilizacyjnego wyrażającego się w wypieraniu cywilizacji industrialnej przez cywilizację opierającą się na wiedzy i informacji, cywilizację gospodarki wirtualnej, skrajnie różnej od swej industrialnej poprzedniczki.

Postępujące procesy globalizacji, rozwój rynków kapitałowych i ponadnarodowych przedsiębiorstw oraz związana z tym złożoność gospodarki, a tym samym rosnące ryzyko biznesu sprawiają, że nie tylko gospodarka i przedsiębiorstwa, ale także ryzyko podlega globalizacji. Wskazuje to na konieczność stałego monitorowania przemian w gospodarce światowej, która w ostatnich latach znajduje się pod silnym wpływem procesów zachodzących w krajach Azji, w tym zwłaszcza przełomowej transformacji w Chinach. Stąd konieczność przede wszystkim analiz z tego zakresu, tym bardziej, że wiążą się z tym złożone zjawiska offsho-ringu, delokalizacji przemysłowej i gospodarczej (Mączyńska 2008m, s. 74).

Globalizacja generalnie, mimo szeregu efektów pozytywnych, wyraźnie wywołuje efekt wypychania, przemieszczania negatywnych zjawisk społeczno-gospodarczych z obszarów (krajów, regionów, aglomeracji, przedsiębiorstw) silniejszych ekonomicznie do słabszych. Dotyczy to przede wszystkim małych i średnich przedsiębiorstw oraz małych gospodarek, które nader często przegrywają w konkurencji z gigantami (Mączyńska 2004j, s. 5).

Wobec nowego paradygmatu rozwojowego oraz wyzwań globalizacyjnych, warunkiem rozwoju przedsiębiorczości i umacniania kondycji przedsiębiorstw staje się odpowiednia synchronizacja polityki mikro- i makroekonomicznej. Wbrew niektórym teoriom, w tym obszarze nie zmniejsza się, a przeciwnie - wzrasta rola państwa w kreowaniu otoczenia przedsiębiorstw, zwłaszcza otoczenia edukacyjnego (Mączyńska 2009k, s. 199). Nowy paradygmat rozwojowy wymusza zmiany w relacjach między biznesem a władzami samorządowymi oraz instytucjami pozabiznesowym. Wymaga to racjonalnej polityki w zakresie pomocy publicznej udzielanej przedsiębiorstwom.

Globalizacja ryzyka sprawia, że warunki funkcjonowania przedsiębiorstw stają się tym trudniejsze, w im większym stopniu na zmiany ustrojowe w gospodarce nakładają się dokonujące się w świecie przemiany paradygmatu rozwojowego, dezindustrializacja i przechodzenie do gospodarki opartej na wiedzy, w tym gospodarki wirtualnej. Wiąże się z tym zagrożenie upadłości przedsiębiorstw. Pod wpływem tych przemian bankructwa mogą się nasilać, co rzutuje na funkcjonowanie i przetrwanie przedsiębiorstw. Stąd też rosnąca waga analiz z zakresu demografii przedsiębiorstw.

W polityce makro- i mikroekonomicznej istotne są ponadto gwarancje, że system nie wymyka się spod kontroli, przeciwnie, jest na tyle przejrzysty, iż umożliwia wczesne identyfiko- 
wanie nieprawidłowości w sektorze przedsiębiorstw, gwarantując tym samym wczesne ostrzeganie inwestorów i kontrahentów (Mączyńska 2009f, s. 57). Łączy się to z koniecznością eliminowania luk informacyjnych, w tym tzw. luki raportowania.

Monitoring i wczesne rozpoznanie zagrożeń jest warunkiem sine qua non podejmowania trafnych decyzji ekonomicznych. Istotne jest przy tym rozpoznanie reakcji przedsiębiorstw na zmiany (w tym zwłaszcza zaostrzanie) polityki gospodarczej i otoczenia instytucjonalno-prawnego.

W związku ze zmianami paradygmatu rozwojowego, dla prawidłowego funkcjonowania i rozwoju przedsiębiorstw niezbędna jest efektywna instytucjonalna infrastruktura biznesu, w tym infrastruktura upadłości, o czym przekonują ujawniające się $\mathrm{w}$ ostatnim okresie z całą ostrością słabości nowoczesnej gospodarki i zagrożenia dla światowego systemu gospodarczego (m.in. poprzez spektakularne bankructwa wielkich przedsiębiorstw i agresywną rachunkowość).

\section{Literatura}

1. Bankructwa przedsiębiorstw - zgodnie z prawem czy ekonomią?, „Kwartalnik Nauk o Przedsiębiorstwie", nr 1/2009.

2. Bauer K., 2009, Zarządzanie informacjami w procesie upadłościowo-naprawczym przedsiębiorstw, Uniwersytet Jagielloński, Kraków.

3. Kuciński K., Mączyńska E., 2005, Wprowadzenie [w:] K. Kuciński, E. Mączyńska, Zagrożenie upadłością, SGH, Warszawa.

4. Mączyńska E., 2009a, Bankructwa-globalny efekt domina [w:] I. Lichniak, Wyzwania ekonomiczne w warunkach kryzysu, SGH, Warszawa.

5. Mączyńska E., 2009b, Bankructwa przedsiębiorstw jako niedostosowanie do przyszłości (analiza w kontekście funkcjonowania sąów gospodarczych [w:] Finanse 2009 - teoria i praktyka. Finanse przedsiębiorstw, Zeszyty Naukowe Uniwersytetu Szczecińskiego, Szczecin.

6. Mączyńska E., 2008c, Bankructwa przedsiębiorstw. Wybrane aspekty instytucjonalne, SGH, Warszawa.

7. Mączyńska E., 2004d, Globalizacja ryzyka a systemy wczesnego ostrzegania przed upadtościa [w:] D. Appenzeller, Upadłość przedsiębiorstw w Polsce w latach 1990-2003. Teoria i praktyka, AE Poznań, Poznań.

8. Mączyńska E., 2009e, Meandry upadtości przedsiębiorstw. Klęska czy druga szansa?, SGH, Warszawa.

9. Mączyńska E., 2009f, Ocena ryzyka upadtości przedsiębiorstwa [w:] A. Fierla, Ryzyko w działalności przedsiębiorstw. Wybrane aspekty, SGH, Warszawa, s. 57.

10. Mączyńska E., 2010g, Rachunkowość a wczesne ostrzeganie przed zagrożeniami działalności gospodarczej [w:] E. Mączyńska, Z. Messner, Zagrożenie działalności gospodarczej a prawo bilansowe, PTE-SK w Polsce, Warszawa.

11. Mączyńska E., 2009h, Siła, tradycja i grzechy rachunkowości, „Rachunkowość”, nr 10.

12. Mączyńska E., 2010i, Syndrom hieny upadłościowej, „Gazeta Bankowa”.

13. Mączyńska E., 2004j, Systemy wczesnego ostrzegania, „Nowe Życie Gospodarcze”, nr 12.

14. Mączyńska E., 2009k, Sytuacje kryzysowe w przedsiębiorstwach [w:] I. Lichniak, Nauka o przedsiębiorstwie. Wybrane zagadnienia, SGH, Warszawa.

15. Mączyńska E., 20091, Upadłość przedsiębiorstwa. Zaprzestanie działalności [w:] I. Lichniak, Nauka o przedsiębiorstwie. Wybrane zagadnienia, SGH, Warszawa.

16. Mączyńska E., 2008m, Zarządzanie w warunkach ekonomii niepewności. Systemy wczesnego ostrzegania [w:] L. Lewandowska, Nowe koncepcje zarządzania i finansowania rozwoju firm regionu łódzkiego, PTE, Łódź. 
17. Sztucki T., 2000, Myśli o biznesie, Difin, Warszawa.

18. Tokarski A., 2010, Przyczyny i symptomy upadtości przedsiębiorstw w gospodarce rynkowej [w:] P. Maśloch, J.M. Stankiewicz, Zarządzanie w XXI wieku, WSB Toruń, Toruń.

19. Tokarski A., 2009, Rola rachunkowości w postępowaniu upadłościowym [w:] T. Kiziukiewicz, Rachunkowość w zarządzaniu jednostkami gospodarczymi, „Zeszyty Naukowe Uniwersytetu Szczecińskiego", Uniwersytet Szczeciński, Szczecin.

20. Tokarski A., Tokarski M., 2006, Rachunkowość źródlem informacji o przewidywaniu upadłości przedsiębiorstw w polskiej gospodarce [w:] T. Kiziukiewicz, Rachunkowość w zarządzaniu jednostkami gospodarczymi, Akademia Rolnicza - Uniwersytet Szczeciński, Szczecin.

21. Ustawa z 28 lutego 2003 roku „Prawo upadłościowe i naprawcze” (Dz.U. nr 60, poz. 535).

\section{The Globalization of Business and the Bankruptcy Risk}

The economy in the world today is becoming increasingly similar to "economic instability".

The progressive processes of globalization, the development of capital markets and transnational companies and the complex and concentrated as a result of this network of connections (global spider web) in the economy mean that not only the economy, business, but also risk are subjected to globalization. This also includes a risk of bankruptcy.

Practice shows that the faster virus spreads to the bankruptcy the stronger is the connection between business attacked with the diseases of insolvency and other, domestic and foreign partners. Globalization intensifies the power of spreading of bankruptcies.

The article presents the impact of the risk of globalization on the bankruptcy risk of firms in the economy. 